\title{
Skuteczność hiperbarii tlenowej w leczeniu ran przewlekłych
}

\section{Effectiveness of oxygen hiperbaria in treating chronic wounds}

\author{
BARBARA MACKIEWICZ1',LEOKADIA REZMERSKA² \\ ${ }^{1}$ Wojskowy Szpital Polowy w Bydgoszczy, Szpitalny Oddział Ratunkowy \\ ${ }^{2}$ Państwowa Wyższa Szkoła Zawodowa we Włocławku, Instytut Nauk o Zdrowiu
}

DOI: http://dx.doi.org/10.21784//wP.2017.013

ISSN: 2451-1846

\section{Streszczenie:}

Wstęp. Rana przewlekła to ubytek skóry powstający w wyniku procesu chorobowego czy urazu, który mimo leczenia zatrzymuje się na etapie stanu zapalnego i nie daje całkowitej odbudowy tkanek oraz podjęcia procesów fizjologicznych. Problem ran przewlekłych wiąże się ze wzrostem występowania chorób cywilizacyjnych. Owrzodzenia troficzne goleni czy z powodu miażdżycy naczyń lub niegojące się rany w zespole stopy cukrzycowej stanowią problem interdyscyplinarny w medycynie. Stosowanie terapii hiperbarycznej stanowi uzupełnienie standardowego postępowania w leczeniu ran przewlekłych, zgodnego ze strategią TIME i leczeniem choroby zasadniczej.

Cel. Celem badań była ocena skuteczności hiperbarii tlenowej w leczeniu ran przewlekłych.

Materiał i metody. Badaniami objęto 31 osób, które były pacjentami Centrum Hiperbarii Tlenowej i Leczenia Ran w Bydgoszczy. Badania wykonano w okresie od października 2016 roku do maja 2017 roku. Badanymi osobami byli pacjenci w wieku 21-80 lat, zarówno kobiety jak i mężczyźni. W badaniach wykorzystano metodę sondażu diagnostycznego. Techniką badań była ankieta. Narzędzie badawcze stanowił kwestionariusz ankiety własnej konstrukcji. 
Wyniki. Wyniki badań zostały poddane opracowaniu i analizie statystycznej, a następnie przedstawione graficznie $\mathrm{w}$ tabelach wraz $\mathrm{z}$ ich opisem.

Wnioski. 1. Skuteczność hiperbarii tlenowej w leczeniu ran przewlekłych nie zależy od płci, wieku, wykształcenia i stanu cywilnego osób badanych. 2 Skuteczność hiperbarii tlenowej w leczeniu ran przewlekłych nie zależy od aktywności fizycznej osób badanych. 3. Skuteczność hiperbarii ia rany przewlekłej u osób badanych.

Słowa kluczowe: rana przewlekła, leczenie, hiperbaria tlenowa

\begin{abstract}
:
Introduction. Chronic wound it is a loss of skin caused by morbidity process or wound which, although treated stops at the stage of inflammation, and does not give any chance of both full re construction of tissues and undertaking physiological processes. The problem of chronic wounds is connected with the increase of civilization diseases. Trophic ulcerations of tibia caused by vessels' atherosclerosis or unhealig wounds connected with the syndrome of diabetic foot make an interdisciplinary problem in medicine. Employing hyperbaric therapy compliment standard procedures in treating chronic wounds in accordance with TIME strategy as well as with treating serious illness.
\end{abstract}

Aim. The aim of this research was the assessment of oxygen hiperbaria in chronic wounds treatment.

Material and methods. 31 patients of the Oxygen Hiperbaria and Wounds Treatment Centre in Bydgoszcz took part in this research. The research was carried from November, 2016 until May, 2017. The patients were people aged 21-80 years old, both women and men. The method of diagnostic survey was used in the research. Questionnaire was the tool for the survey.

Results. The results of the research were processed and then presented in tables and graphs along with their description.

Conclusions. 1 . The effectiveness of oxygen hiperbaria in treating chronic wounds does not depend on represented sex, age, education or marital status of the patients. 2. The effectiveness of oxygen hiperbaria in treating chronic wounds does not depend on patients' physical activities. 3. The effectiveness of oxygen hiperbaria in treating chronic wounds does not depend on the amount of time which has passed since the beginning of the onset of chronic wound in case of treated patients. 
Keywords: chronic wound, treatment, oxygen hiperbaria

\section{Wstęp}

Problem trudno gojących się ran stanowi poważne wyzwanie dla medycyny i szacuje się, że może wzrosnąć wraz z rozwojem chorób cywilizacyjnych, takich jak cukrzyca czy niewydolność naczyń tętniczych i żylnych. W wyniku upośledzenia mikrokrążenia i niedostatecznego zaopatrywania tkanek w tlen dochodzi do hipoksji otaczających owrzodzenie tkanek. Tylko dostarczenie uszkodzonym i niedokrwionym tkankom tlenu może przyspieszyć gojenie się rany przewlekłej, a nawet jej całkowite wyleczenie. Stosowanie tlenu hiperbarycznego przyspiesza produkcję kolagenu, pobudza angiogenezę oraz ogranicza infekcję bakterii beztlenowych i mikrotlenowych.

Pierwszą osobą wykorzystującą sprężone powietrze do leczenia ran był Henshaw, który w tym celu w 1662 roku zbudował urządzenie „domicilium” służące do leczenia chorób płuc, szkorbutu, krzywicy czy stanów zapalnych. Jednak dopiero odkrycie tlenu przez Priestleya w 1774 roku spopularyzowało stosowanie tlenu w celach leczniczych, gdzie $\mathrm{w}$ ten sposób próbowano leczyć trąd. Jednak w związku z opisywaną przez ówczesnych naukowców toksycznością tlenu i awaryjnością wykorzystywanego sprzętu badania nad tą formą terapii wielokrotnie przerywano i zawieszano. Dopiero stworzenie $\mathrm{w} X \mathrm{X}$ wieku komory $\mathrm{z}$ rzeczywistym nadciśnieniem tlenu zapoczątkowało leczenie chorób serca i choroby dekompresyjnej [1].

Terapia hiperbaryczna to nieinwazyjna metoda terapeutyczna wykorzystująca stuprocentowy tlen pod zwiększonym ciśnieniem atmosferycznym. Zabiegi przeprowadzane są w specjalnym pomieszczeniu, tak zwanej komorze hiperbarycznej. Założeniem terapii hiperbarycznej jako metody leczenia jest poprawienie naturalnych mechanizmów gojenia i procesów naprawczych 
w przypadku ran oraz innych schorzeń. Terapia tlenem hiperbarycznym jest metodą leczniczą lub wspomagającą leczenie wielu chorób chirurgicznych jak i niechirurgicznych. Należy ona do najbardziej efektywnych metod dostarczania tlenu do wszystkich komórek ciała, gdyż ciśnienie wyższe niż atmosferyczne ułatwia przenikanie tlenu przez fizjologiczne bariery tkanek dzięki czemu może on być dostarczony tam, gdzie nie jest to możliwe w warunkach fizjologicznych i skutecznie wysyca tkanki tlenem. Doprowadza to do regeneracji tkanek, neowaskularyzacji, zmniejsza stan zapalny i wpływa na poprawę gojenia się ran w przypadku takich schorzeń jak stopa cukrzycowa, zakażenia tkanek miękkich i kości czy owrzodzenia troficzne pochodzenia naczyniowego. Skojarzenie klasycznego leczenia $\mathrm{z}$ terapią hiperbaryczną umożliwia pacjentom szybszy powrót do zdrowia i życiowej aktywności oraz obniża koszty ponoszone z tytułu wielokrotnego powtarzania rutynowych procedur medycznych. Na obecnym etapie wiedzy hiperbaria tlenowa stanowi tylko uzupełnienie klasycznego leczenia i nie może być stosowana jako metoda z wyboru [2].

Celem badań własnych była ocena skuteczności hiperbarii tlenowej w leczeniu ran przewlekłych w zależności od czynników socjodemograficznych i klinicznych osób badanych.

\section{Materiał i metody}

W badaniach uczestniczyło 31 osób $\mathrm{z}$ raną przewlekłą pochodzenia naczyniowego, zespołem stopy cukrzycowej i urazami mechanicznymi. Dominująca grupę osób stanowili mężczyźni - 77,4\%, natomiast najliczniejszą grupą wiekową były osoby w wieku 60-80 lat, co stanowiło - 51,6\%. Badania przeprowadzono w okresie od października 2016 roku do maja 2017 roku wśród pacjentów Centrum Hiperbarii Tlenowej z Poradnią Leczenia Ran w Bydgoszczy. W badaniach zastosowano metodę sondażu diagnostycznego z wykorzystaniem kwestionariusza ankiety własnej konstrukcji. Na 
przeprowadzenie badań uzyskano zgodę Komisji Bioetycznej przy Kujawsko-Pomorskiej Okręgowej Izbie Lekarskiej w Toruniu (OIL67/KB/149/2016) oraz zgodę Kierownika Medycznego Centrum Hiperbarii Tlenowej i Leczenia Ran w Bydgoszczy. Do analizy statystycznej wykorzystano test chi-kwadrat Pearsona. Za poziom istotności statystycznej przyjęto wartości $\mathrm{p}<0,05$.

\section{Wyniki}

Czas po jakim zauważono poprawę gojenia się rany nie zależał od płci badanych osób ( $\mathrm{p}=0,181)$. Zauważono jednak, że u kobiet częściej odnotowywano poprawę w okresie po 2 tygodniach leczenia, zaś u mężczyzn w okresie po 6 tygodniach leczenia (ryc. 1).

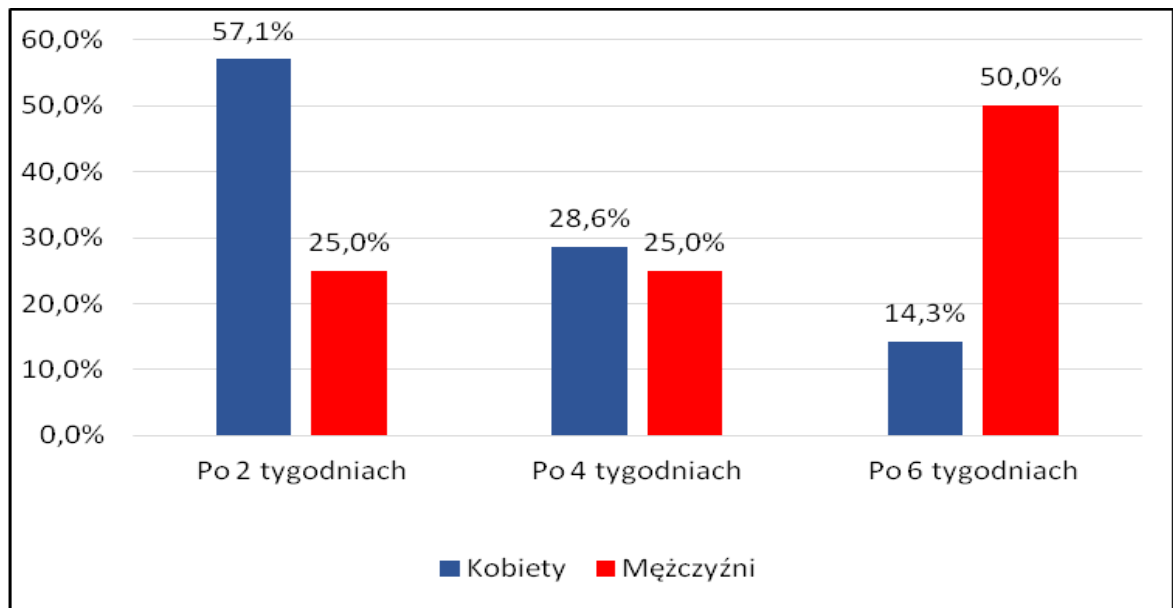

Rycina 1. Czas po jakim nastąpiła poprawa gojenia się rany a płeć osób badanych.

Źródło: wynik badań własnych.

Potwierdzono brak istotnych statystycznie zależności pomiędzy czasem, po jakim zauważono poprawę gojenia się rany, a wiekiem badanych osób ( $\mathrm{p}=0,116)$, (ryc. 2). 


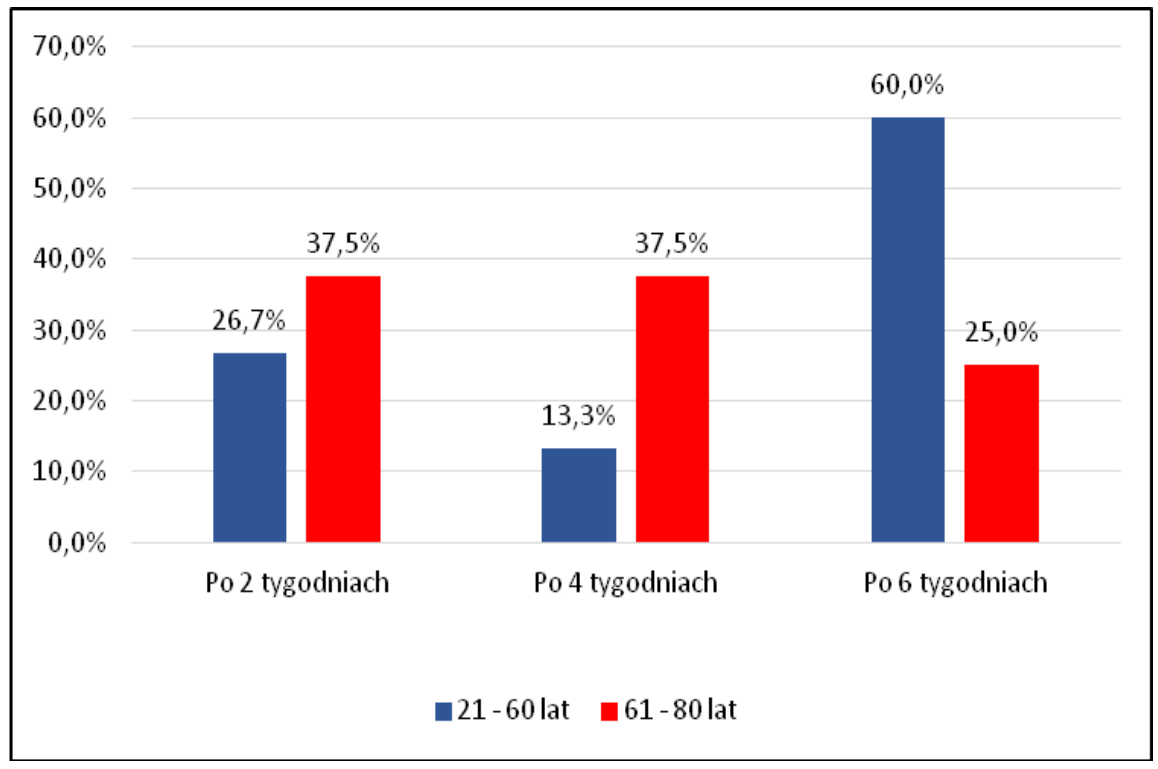

Rycina 22. Czas po jakim nastąpiła poprawa gojenia się rany a wiek osób badanych.

Źródło: wyniki badań własnych.

Czas, po jakim zauważono poprawę gojenia się rany nie zależał od wykształcenia badanych osób $(\mathrm{p}=0,264)$. Zauważono jednak, że osoby, mające coraz wyższe wykształcenie częściej wskazywały na okres gojenia po 2 tygodniach lub po 4 tygodniach, zaś osoby mające coraz niższe wykształcenie, na okres po 6 tygodniach (ryc. 3). 


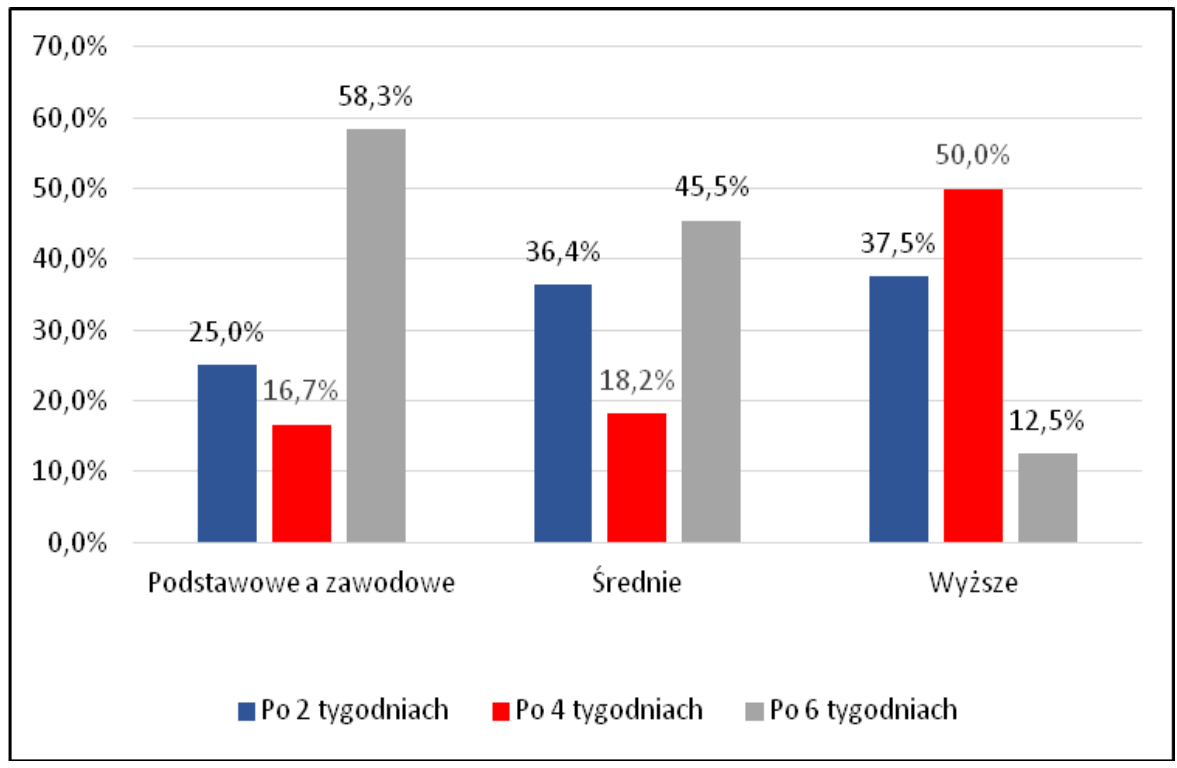

Rycina 3. Czas po jakim nastąpiła poprawa gojenia się rany a wykształcenie osób badanych.

Źródło: wynik badań własnych.

Potwierdzono brak istotnych statystycznie zależności pomiędzy czasem po jakim zauważono poprawę gojenia się rany, a stanem cywilnym badanych osób $(\mathrm{p}=0,143)$, (ryc. 4). 


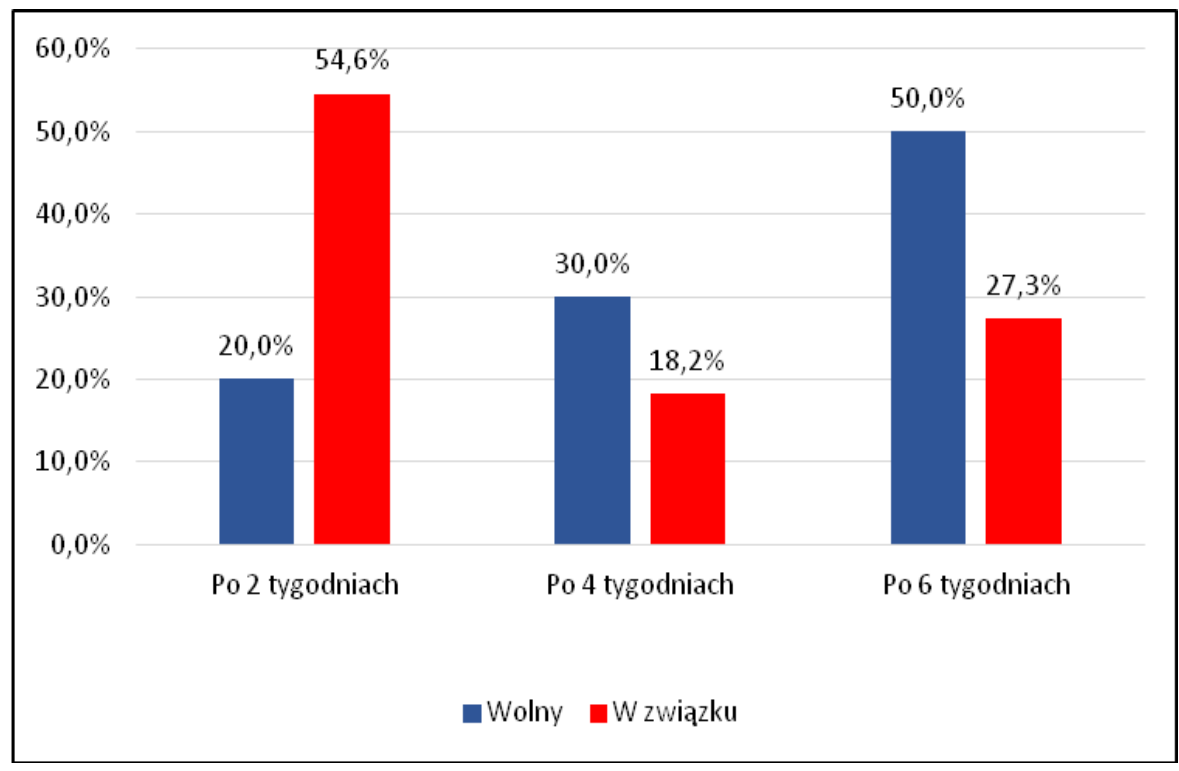

\section{Rycina 4. Czas po jakim nastąpiła poprawa gojenia się rany a stan} cywilny osób badanych.

Źródło: wynik badań własnych.

Czas po jakim zauważono poprawę gojenia się rany nie był uzależniony od czasu, jaki upłynął od powstania trudno gojącej się rany ( $\mathrm{p}=0,395)$, (ryc. 5). 


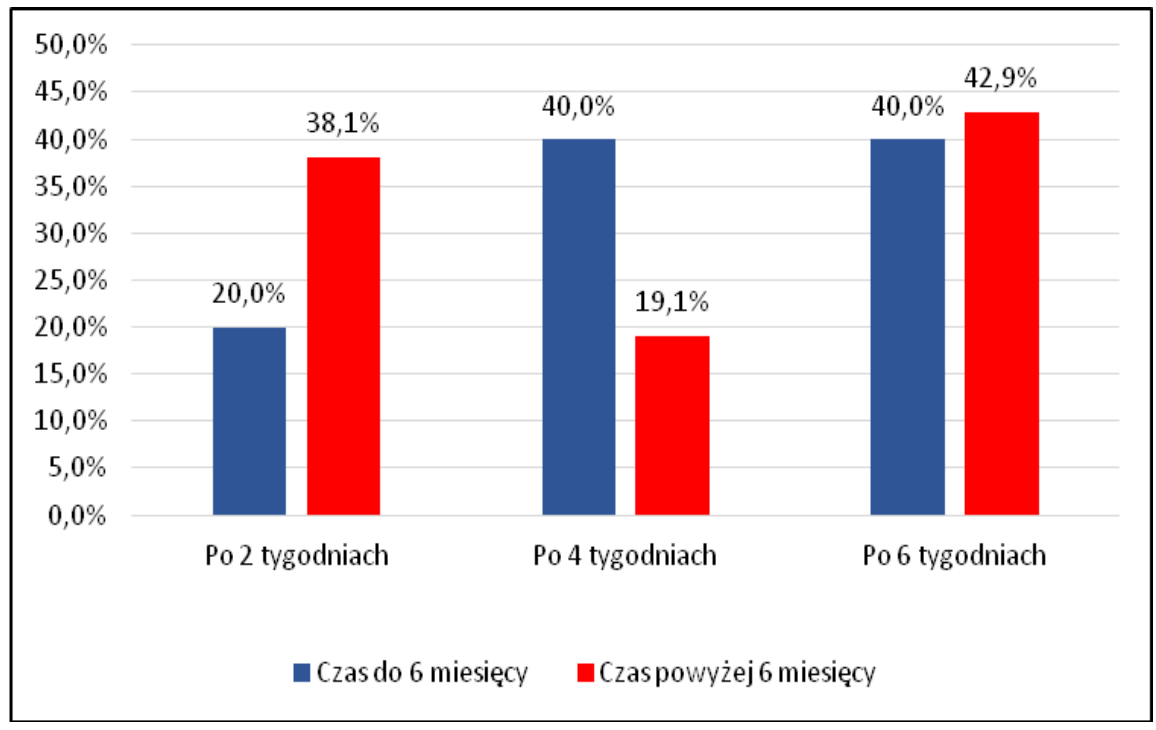

Rycina 54. Czas po jakim nastąpiła poprawa gojenia się rany a czas jaki upłynął od powstania trudno gojącej się rany.

Źródło: wynik badań własnych.

Potwierdzono także brak istotnej statystycznie zależności pomiędzy czasem po jakim zauważono poprawę gojenia się rany, a aktywnością fizyczną badanych realizowaną w okresie stosowania hiperbarii tlenowej $\mathrm{w}$ porównaniu do okresu przed zabiegami ( $p=0,205)$, (ryc. 6). 


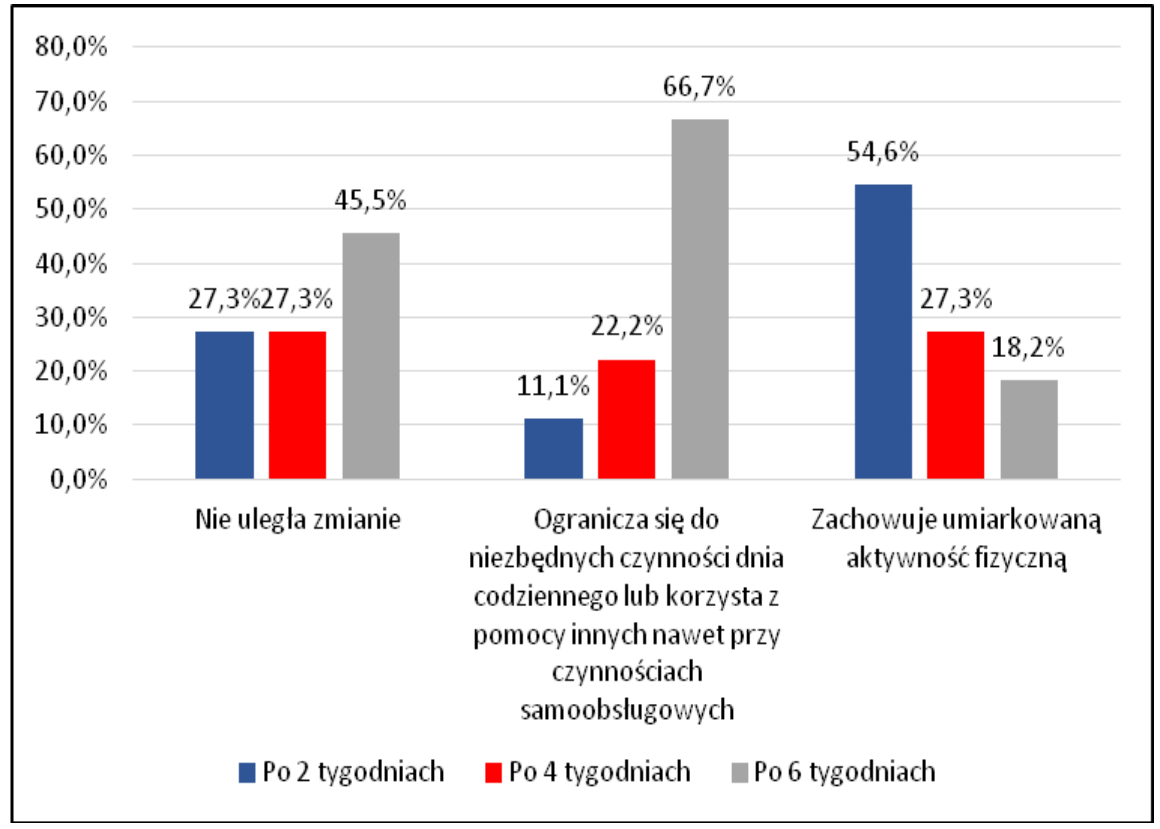

Rycina 6. Czas po jakim nastąpiła poprawa gojenia się rany a aktywność fizyczna w okresie stosowania zabiegów hiperbarii tlenowej.

Źródło: wynik badań własnych.

\section{Dyskusja}

Analiza wyników badań własnych nie potwierdziła hipotezy dotyczącej skuteczności leczenia ran przewlekłych leczonych metodą hiperbarii tlenowej w zależności od płci osób badanych $(\mathrm{p}=0,181)$. Zauważono jednak, że u kobiet częściej odnotowywano poprawę w okresie po 2 tygodniach leczenia $(57,1 \%)$, zaś u mężczyzn dopiero w okresie po 6 tygodniach leczenia (50\%). Podobne wyniki uzyskano w badaniu przeprowadzonym w 2014 roku podczas badań przeprowadzonych w Collegium Medicum Uniwersytetu Jagiellońskiego w Krakowie. Przebadano wówczas 100 pacjentów z owrzodzeniem 
w rozpoznanym zespole stopy cukrzycowej. Kobiety stanowiły $48 \%$ badanej grupy, a analiza statystyczna przeprowadzonych badań nie dowiodła istotnych związków pomiędzy płcią, a poprawą gojenia owrzodzeń pomiędzy początkiem, a końcem leczenia tlenem hiperbarycznym [3]. Natomiast badania przeprowadzone w roku 2013 we wspomnianym wyżej zakładzie, w którym udział wzięły osoby poddawane zabiegom hiperbarii tlenowej $\mathrm{z}$ zakażeniem tkanek miękkich dowiodły, że leczenie dało dobre wyniki, ale u jednej z pacjentek z zakażoną raną po usunięciu pęcherzyka żółciowego metodą laparotomii uzyskano znaczną poprawę już po 3 zabiegach [4].

W badaniach własnych wiek badanych mieścił się w przedziale 21-80 lat, a najliczniejszą grupę stanowiły osoby w wieku od 61 do 80 lat - 51,6\%. Stwierdzono brak istotnych statystycznie zależności pomiędzy czasem po jakim zauważono poprawę gojenia się rany,a wiekiem badanych osób $(\mathrm{p}=0,116)$. Przedstawione rezultaty badań wykazują brak wpływu wieku na tempo gojenia rany przewlekłej, chociaż wyniki wskazują, że w grupie tej, poprawę gojenia rany zaobserwowano dopiero po 6 tygodniach. Podobne wyniki zostały opublikowane po przeprowadzeniu w 2013 roku badań pacjentów leczonych w komorze hiperbarycznej Małopolskiego Centrum Oparzeniowo-Plastycznego, Replantacji Kończyn z Ośrodkiem Terapii Hiperbarycznej w Krakowie $\mathrm{z}$ powodu przewlekłych ran owrzodzeniowych goleni. W wybranej grupie 6 osób, w trakcie prowadzonej terapii doszło do całkowitego wyleczenia lub znacznej poprawy, jednak liczba sprężeń wahała się od 10 do 30, przy średniej 24 sprężenia, a ilość przeprowadzanych zabiegów rosła proporcjonalnie do wieku [5].

W badaniach własnych nie można przyjąć również hipotezy mówiącej, że czas po jakim zauważono poprawę gojenia się rany zależał od wykształcenia badanych osób $(\mathrm{p}=0,264)$. Zauważono jednak, że osoby mające coraz wyższe wykształcenie częściej wskazywały na okres gojenia po 2 tygodniach lub po 4 tygodniach, zaś osoby mające coraz niższe wykształcenie, na okres po 6 tygodniach. 37,5\% badanych 
z wyższym wykształceniem zauważyło poprawę gojenia się rany już po 2 tygodniach, natomiast aż 58,3\% badanych posiadających wykształcenie podstawowe i zawodowe zauważyło poprawę gojenia się rany przewlekłej dopiero po upływie 6 tygodni. W trakcie analizy publikacji opisującej badania przeprowadzone w latach 2002-2003 na 52 chorych $\mathrm{z}$ owrzodzeniami troficznymi na tle przewlekłej niewydolności żylnej hospitalizowanych w Centrum Leczenia Oparzeń w Siemianowicach Śląskich wyciągnięto wnioski, że powodem nawrotów owrzodzenia troficznego jest zwykle brak konsekwencji chorego w leczeniu. Dowiedziono, że pacjentów należy informować, iż zabiegi hiperbaryczne likwidują objawy, a nie przyczynę choroby. Niezastosowanie się do zaleceń, takich jak terapia uciskowa, zapobieganie uszkodzeniom mechanicznym oraz zaniechanie leczenia flebologicznego doprowadzą do szybkiego nawrotu owrzodzenia. Dlatego oprócz przygotowania internistycznego do proponowanego leczenia bardzo ważna jest współpraca $\mathrm{z}$ psychologiem i właściwa ocena zdolności pacjenta do analizy otrzymanych zaleceń i ich przestrzegania. Pozytywny wynik leczenia owrzodzeń troficznych podudzi zależy od stadium przewlekłej niewydolności żylnej i współpracy z pacjentem. Choroba dotyczy często ludzi starszych, samotnych, zaniedbanych, wymagających szczególnej opieki. Należy zatem przyjąć, że na czas gojenia ma wpływ nie tyle poziom wykształcenia, co przyjęcie prozdrowotnych postaw prezentowanych przez pacjenta, które są wprost proporcjonalne do poziomu wykształcenia [6].

$\mathrm{Na}$ podstawie przeprowadzonych badań własnych nie potwierdzono istotnych statystycznie zależności pomiędzy czasem po jakim zauważono poprawę gojenia się rany,a stanem cywilnym badanych osób $(\mathrm{p}=0,143)$. Jednak na uwagę zasługuje fakt, że poprawę gojenia się rany przewlekłej po 2 tygodniach zauważono u $54,7 \%$ pacjentów będących w związkach. Prawdopodobnie uwarunkowane jest to tym, że pacjenci pozostający w stałych związkach mają najczęściej lepszą sytuację ekonomiczną niż osoby samotne, tym bardziej, że 51,6\% osób biorących udział w badaniu stanowią osoby w wieku 61-80 lat, 
a więc pozostające na emeryturach czy rentach chorobowych. Podobne wnioski uzyskano analizując wyniki badań przeprowadzonych w Wojewódzkiej Poradni Chorób Naczyń Szpitala Zakonu Bonifratrów oraz w Niepublicznym Zakładzie Opieki Zdrowotnej - Centrum Medyczne - Chirurgia Naczyń - Tomasz Aleksiejew Kleszczyński, w Krakowie, w okresie od marca do czerwca 2012 roku, dotyczące oceny jakości życia pacjentów z owrzodzeniami żylnymi kończyn dolnych. $\mathrm{Na}$ ich podstawie można wyciągnąć wniosek, że jakość życia takich pacjentów, nie zależy od czynników środowiskowych, w tym także od stanu cywilnego. Autorzy badań stwierdzili, że uzyskanie postępu gojenia się rany jest trudne, często zatrzymuje się na jednym z początkowych etapów, ale zdarzają się również nawroty. Z wyników przeprowadzonych badań wynikało, że pacjenci nie stosują się do zaleceń głównie z powodów ekonomicznych, a tylko 7\% badanych mogło całkowicie zaspokoić swoje potrzeby. Może to stanowić częściowe wyjaśnienie wydłużenia procesu gojenia się ran [7].

Uzyskane wyniki badań własnych pozwalają na stwierdzenie, że skuteczność leczenia ran przewlekłych metodą hiperbarii tlenowej nie jest uzależniona od czasu jaki upłynął od powstania trudno gojącej się rany $(\mathrm{p}=0,395)$. Wśród $20,0 \%$ badanych pacjentów $\mathrm{z}$ raną nie starszą niż 6 miesięcy zauważyło poprawę gojenia się ran po 2 tygodniach stosowania zabiegów hiperbarycznych, a $40,0 \%$ badanych zauważyło poprawę po 4 czy 6 tygodniach trwania terapii. Natomiast, aż 38,1\% pacjentów z raną starszą niż 6 miesięcy zauważyło poprawę gojenia się rany już po 2 tygodniach trwania terapii, a tylko 19,1\% po 4 tygodniach. Analizując literaturę opisującą badania $\mathrm{w}$ zakresie gojenia się ran przewlekłych spotkano się z wynikami badań publikowanymi przez grupę badaczy Center of Diabetology and Metabolic Disease, Niguarda Hospital, Department of Anesthesia and Hyperbaric Medicine, Geleasis Institute, Milan, Italy. Wśród doniesień tego ośrodka na uwagę zasługują wyniki badań przedstawione w 2003 roku przez Kesslera i współpracowników. Brało w nich udział 28 pacjentów z cukrzycą trwającą od 6 do 18 lat, w tym $87 \%$ badanych chorowało na cukrzycę 
insulinozależną $\mathrm{z}$ towarzyszącym owrzodzeniem, bez klinicznych objawów angiopatii, przy czym wszyscy badani zgłaszali objawy neuropatii. Uczestnicy badania poddawani byli zabiegom terapii hiperbarycznej 2 razy dziennie przez 5 dni, w ciągu 2 tygodni. Głównym ocenianym parametrem był rozmiar owrzodzenia. W 15 dniu trwania terapii wielkość owrzodzenia zmniejszyła się znacznie w porównaniu z grupą kontrolną, a dwa tygodnie później redukcja rozmiaru owrzodzenia $\mathrm{w}$ grupie badanej i kontrolnej była porównywalna. $\mathrm{W}$ trzecim tygodniu badania nie wykazano różnicy w zmniejszaniu się owrzodzenia w obydwu grupach, a po 4 tygodniach całkowite wyleczenie zaobserwowano u 2 badanych, natomiast $\mathrm{u}$ żadnego $\mathrm{z}$ grupy kontrolnej [8].

W wyniku przeprowadzonych badań własnych wykazano także brak istotnej statystycznie zależności pomiędzy czasem po jakim zauważono poprawę gojenia się rany, a aktywnością fizyczną badanych w okresie stosowania hiperbarii tlenowej w porównaniu do okresu przed zabiegami $(\mathrm{p}=0,205)$. Tylko 11 osób $(35,5 \%)$ badanych wskazało, że zachowuje umiarkowaną aktywność fizyczną. Taka sama ilość przebadanych pacjentów deklaruje, że stopień aktywności w czasie trwania sesji zabiegów hiperbarycznych nie uległ i jest taki sam, jak przed rozpoczęciem terapii. W badaniach przeprowadzonych w 2014 roku w Collegium Medicum Uniwersytetu Jagiellońskiego w Krakowie zastosowano również kwalifikację chorych ze względu na wykonywaną aktywność fizyczną. Najliczniejszą grupą wśród badanych były osoby chodzące (58\%), 30\% badanych korzystała z pomocy sprzętu, a 6\% badanych stanowiła grupa leżących. Na podstawie analizy klasyfikacji owrzodzeń według skali Wagnera dowiedziono, że nie występują istotne różnice w czasie w jakim nastąpiła poprawa gojenia się rany [9]. 


\section{Wnioski}

1. Skuteczność hiperbarii tlenowej w leczeniu ran przewlekłych nie zależy od płci osób badanych. Jednak pomimo tego na uwagę zasługuje fakt, że pierwsze objawy gojenia się rany występują wcześniej u kobiet, a co się z tym wiąże po mniejszej ilości sprężeń.

2. Skuteczność hiperbarii tlenowej w leczeniu ran przewlekłych nie zależy od wieku osób badanych. Zauważono jednak prawidłowość, że poprawa gojenia się rany w grupie badanych w wieku 61-80 lat jest najwyższa dopiero po 6 tygodniach stosowania zabiegów, a więc skuteczność leczenia ran tą metodą wzrasta wraz z ilością sprężeń.

3. Skuteczność hiperbarii tlenowej w leczeniu ran przewlekłych nie zależy bezpośrednio od wykształcenia osób badanych. Wpływ pośredni na proces gojenia się ran ma jednak zachowanie postaw prozdrowotnych i samoświadomość pacjenta co do właściwego postępowania z chorobą pierwotną. Zachowania prozdrowotne pacjenta jednak wiążą się z poziomem wykształcenia.

4. Skuteczność hiperbarii tlenowej w leczeniu ran przewlekłych nie zależy bezpośrednio od stanu cywilnego osób badanych. Pomimo tego, że wyniki nie wykazują istotnego znaczenia statystycznego jednak zaobserwowano wpływ sytuacji ekonomicznej na poprawę gojenia się rany. Wolniejsze gojenie się zaobserwowano $u$ osób samotnych oraz jak można podejrzewać o niższym statusie ekonomicznym.

5. Skuteczność hiperbarii tlenowej w leczeniu ran przewlekłych nie zależy od czasu jaki upłynął od powstania rany przewlekłej u osób badanych. Uzyskane jednak wyniki badań chociaż bez istotnego znaczenia statystycznego dowodzą, że tempo z jakim dochodzi do poprawy gojenia się ran jest wyższe po rozpoczęciu sesji zabiegów, po czym następuje jego 
spowolnienie, ale u wszystkich badanych odnotowano trwałą poprawę lub wygojenie już w 4-6 tygodnia trwania terapii.

6. Skuteczność hiperbarii tlenowej w leczeniu ran przewlekłych nie zależy od aktywności fizycznej osób badanych. Na uwagę jednaj zasługuje wynik osiągnięty przez grupę badanych zachowujących umiarkowaną aktywność fizyczną, gdzie aż ponad połowa $\mathrm{z}$ nich uzyskała poprawę leczenia już po 2 tygodniach terapii.

\section{Zalecenia dla praktyki pielęgniarskiej}

Stosowanie hiperbarii tlenowej w leczeniu ran przewlekłych stanowić powinno wypadkową pomiędzy zapobieganiem powikłań powodowanych przez toksyczne działanie tlenu pod ciśnieniem, a korzyścią płynącą z dostarczania tlenu tkankom w celu ich odbudowy i regeneracji. Wpływ pośredni na proces gojenia się ran ma także zachowanie postaw prozdrowotnych i samoświadomość pacjenta co do właściwego postępowania $\mathrm{z}$ chorobą pierwotną, a także postępowanie $\mathrm{z}$ raną przewlekłą zgodne z zaleceniami strategii TIME. W dążeniu do uzyskania wygojenia rany przewlekłej należy koordynować działania zespołu terapeutycznego jak również środowiska rodzinnego i samego pacjenta.

\section{Bibliografia/Bibliography:}

1. Paprocki J., Gackowska M., Pawłowska M., Woźniak A. Aktualne zastosowanie hiperbarii tlenowej. Medycyna Rodzinna. 2016;4:217-222.

2. Łatka U., Kuliński W., Knefel G., Sieroń A. Aktualny stan medycyny hiperbarycznej w Polsce. Polska Balneologia. 2009;1:7-15. 
3. Walewska E., Ścisło L., Puto G., Klich M., Szczepanik A. Zastosowanie tlenu hiperbarycznego $\mathrm{w}$ leczeniu zespołu stopy cukrzycowej - doświadczenia własne. Leczenie Ran. 2016;13(2):46-47.

4. Kobielska E., Chrapusta A., Mudyna W. Wstępne wyniki leczenia tlenem hiperbarycznym zakażeń tkanek miękkich. Forum zakażeń. 2014;5(2):63-64.

5. Chrapusta A., Kobielska E., Mudyna W. Wstępna ocena zastosowania hiperbarii tlenowej w leczeniu przewlekłych ran goleni - doświadczenia własne. Leczenie Ran. 2014;11(4):175176.

6. Kawecki M., Sieroń A., Glik J., Nowak M., Szymańska B., Knefel G. Rola hiperbarii tlenowej w leczeniu chirurgicznym troficznych owrzodzeń podudzi spowodowanych przewlekłą niewydolnością żylną. Balneologia Polska. 2006;3:150-155.

7. Ścisło L., Socha T., Walewska E., Puto G., Kłęk S., Szczepanik A., Czupryna A. Jakość życia pacjentów z owrzodzeniami żylnymi kończyn dolnych. Hygeia Public Health. 2015;50(1):149-154.

8. Duda-Raszewska B., Strojek K. Terapia hiperbaryczna w zespole stopy cukrzycowej. Lekarz. 2009;1,67-68.

9. Walewska E., Ścisło L., Puto G., Klich M., Szczepanik A. Zastosowanie tlenu hiperbarycznego $\mathrm{w}$ leczeniu zespołu stopy cukrzycowej - doświadczenia własne. Leczenie Ran. 2016;13(2):46-47. 